\title{
Carlin Romano, America the Philosophical
}

New York, NY, Random House, 2012, 688 pages

\section{Giovanni Maddalena}

\section{OpenEdition}

1 Journals

\section{Electronic version}

URL: http://journals.openedition.org/ejpap/665

DOI: 10.4000/ejpap.665

ISSN: 2036-4091

\section{Publisher}

Associazione Pragma

\section{Electronic reference}

Giovanni Maddalena, "Carlin romano, America the Philosophical », European Journal of Pragmatism and American Philosophy [Online], VIII-2 | 2016, Online since 16 January 2017, connection on 24 September 2020. URL : http://journals.openedition.org/ejpap/665 ; DOI : https://doi.org/10.4000/ejpap.665

This text was automatically generated on 24 September 2020 .

\section{(c) (i) $(9)$}

Author retains copyright and grants the European Journal of Pragmatism and American Philosophy right of first publication with the work simultaneously licensed under a Creative Commons AttributionNonCommercial-NoDerivatives 4.0 International License. 


\title{
Carlin ROMANO, America the Philosophical
}

New York, NY, Random House, 2012, 688 pages

\author{
Giovanni Maddalena
}

\section{REFERENCES}

Carlin Romano, America the Philosophical, New York, NY, Random House, 2012, 688 p.

1 Although questionable for its style and method, irritating in its conclusions and judgments, and political in the broad sense of the word, Carlin Romano's book is a courageous work that fully belongs to the pragmatist tradition. It recalls the style and the tone of some Italian pragmatists like Papini and Prezzolini, whose books lacked perhaps some deep technical tools but were apt to shake the intellectual world and substantially to the point in many critiques. As the Italian pragmatists for their time, Romano points out the pathological weakness of the mainstream professional philosophy and suggests his way out of a sterile fashion of understanding philosophy. This review will tackle his main polemical topic, signal some flaws, and offer a different way out from the situation that Romano indicates.

\section{With Isocrates and Rorty Against Analytic Philosophy}

2 The pattern of America the Philosophical runs as follows. Philosophy in America started with some profound thinkers - the "cavalcade" of classic pragmatists - who invented something new, a philosophy different from both rationalism and empiricism, related to experience in a special and broad sense. Far from any justificatory and transcendentalist mood, classic pragmatists fostered a discursive, practical understanding of our reasoning that was completely involved with the actual 
development of science, medicine, education, religion, and politics. When the first wave of the cavalcade ended, the philosophical field was taken over by analytic epistemology that transformed a living and interesting philosophy in a technique that ended up in a complete foreignness to relevant existential problems. This move - largely due to neopositivists and Quine - eclipsed the role of philosophers as public intellectuals.

However, the role of leading intellectuals did not remain empty. Many important figures in psychology, education, civil rights movements, literary critique, and communication undertook the task of pointing out topics and changes of mentality that epistemologists deserted. The long and interesting track of these figures singles out a great final alternative between two ways of understanding philosophy: either philosophy is a long justificatory enterprise or it is a practical suasion. Romano presents the alternative with two heroes for each part, so that you can read the radical splitting by confronting Socrates and Isocrates or, in recent times, Rawls and Rorty.

4 Romano takes side with the latter against the former, joining an anti-rationalist movement that has had an important role in the philosophy of the last two centuries. However, the kind of anti-rationalism that Romano advocates inserts him within the most typical pragmatist tradition. Pragmatism is original insofar as it presents a form of rationality different from both the Enlightenment project and the Romantic idealist or Nietzschean evasion from it. Like the great German philosopher, Romano pinpoints Socrates as the image of rationalism. Socrates breaks up reality into pieces, isolating them and then questioning them and accepting only one form of rationality as their justification. According to Romano, this sort of justification runs in all philosophy, from Socrates to Quine passing through Kant. Differently from Nietzsche, though, Romano proposes no revolution of values or superhuman overtaking. On the contrary, Romano wants to align himself with pragmatists by rescuing the Isocratic alternative, which would be to think that "it is far superior to have decent judgments about useful matters, than to have precise knowledge about useless things" (550). What would be the useful matters? Romano lists politics and the issues of citizens (551), moral sensibility (552), education (560). As Romano pictures him, Isocrates is a precursor of Rorty's ideal of cosmopolitism, well represented nowadays by some of Obama's speeches. Rhetoric is not a mean to an end but the heart of a philosophy that is aware of its fallibility, of the impossibility of attaining truth in practical vital matters, and of the uselessness of looking for it in theoretical fields.

\section{Critical Remarks}

5 I have no doubts about the pertinence of Romano's book to the pragmatist tradition. In 1907 Giuseppe Prezzolini, at the time editor of the "Leonardo" wrote a book called L'arte di persuadere (The art of persuading) advocating the use of lies in public life and defending his statement with a reference to pragmatism. The pragmatist tradition has to do with suasion and practical reasoning: it is the task of pragmatist scholars to articulate and specify these terms. Besides, the broad cultural landscape of characters that Romano presents is worth reading and introduces to many aspects of American culture that should not escape to scholars of pragmatism. Finally, I think that Romano correctly targets the serious problem of the public irrelevance of mainstream epistemology and, notwithstanding his journalistic style, I find his proposal philosophically interesting and worth discussing. That is why I will concentrate my 
critical remarks on what I think is the heart of his proposal hoping to provoke further debates.

First, a critical remark has to be addressed on Romano's method of presenting philosophers and intellectuals. The method is heavily psycho-biographical. As much as it can be interesting and illuminating, philosophies - professional or not - do not coincide with their proponents' biography and psychological profile. The risk with such an approach is to lean toward moralism, where behavior decides of the worthiness of thought. Fortunately, as Peirce noted in his celebrate Cambridge conference on vital topics, this is an attitude that philosophy abandoned since ancient Greece (EP2: 27-41). If there is something good about the Socratic tradition is that it helped severing personal aspects from scientific organized thought. Then, I agree with Romano in deprecating the excess of this separation in contemporary philosophy, but in general it has been a good device not to link freedom of thought to consistency of behavior, distinguishing lay philosophy from religious activities. Certainly, this reliance on biography comes from the journalistic trail from which Romano's chapters come and one can understand that people are more interested in psycho-biographical details than in technical account of pattern of thought. However, a little more work on the philosophical technique (and a few less pages) would have added weigh to Romano's main thesis and would have avoided the pruderie which is always a signal of any kind of moralism, even when it wants to be anti-moralist.

7 Second, as for the content, Romano opens up a possible debate on the nature of philosophy but his solution is not the only option and, above all, it is not the only pragmatist option. Consistently with a fundamental pragmatist insight, Romano understands that irrationalism or existentialism are not a real alternative to rationalism. He picks up Rorty's reading of pragmatism because it seems to be a viable alternative not to give up to reasoning even disagreeing with any form of rationalist project. I agree with the intention but many other options are open. Simply remaining within the pragmatist tradition, different kinds of pragmatist rationality have been presented by Susan Haack, Joe Margolis, Vincent Colapietro, Fernando Zalamea (to quote but an handful of them). All of them tried different ways to refuse the analytic pattern in different degrees and to go towards forms of rationality that would avoid rationalism without abandoning the important results of analytic philosophy. In many of these alternative versions of reasoning there is room for truth and teleology as well as for aesthetics, politics, and education. Papini observed that pragmatism is a method, a corridor that gives access to many rooms in which very different people could be intent to different goals (Papini 1905). Is it not too narrow a view to limit pragmatism to its cosmopolitan political-moral version? Pragmatism is indeed an incomplete project. I think it is Romano's merit to show this incompleteness through a history of effects related to public life. Pragmatism did not reach a final version of itself and a univocal answer to the challenge of introducing a new form of rationality. Classic pragmatists forged interesting innovative tools like abduction, fallibilism, metaphysical realism, stream of consciousness, radical empiricism, instrumental logic, problem solving method of education, conversation by gestures, and so on. Names are already telling: they tried to combine theory and practice well beyond any previous philosophy. However, they did not realize how much revolutionary their move was and they never reached a full account of this new kind of rationality. 
Being unfinished is perhaps one of the biggest sources of interest for pragmatism today. Pragmatist tools can be used for different projects, including a fair amendment of analytic philosophy. I think that Romano blows out this last possibility by underling how much the analytic philosophy is far from seriously engaging political, esthetical, social issues in ways that would be helpful to ordinary people. However, I think that he does not realize that the topic of truth and justice could receive an interesting new spin from pragmatism and become relevant again for discussing politics, esthetics, and social problems. Pragmatists are not necessarily against metaphysics or religion or values. On the contrary, just because they appreciated a full understanding of experience, they grasped the importance of everything that was helping human beings in their acting and discovering the world, in their adjustment to the environment. They really opposed the a-priori metaphysics as well as transcendentalism insofar as related to apriorism; they opposed formal churches but not religious sense; they were against the principle of authority but not against tradition. Therefore, even though Romano's cosmopolitan way to complete pragmatism is certainly an open possibility, I do not think that this is the most loyal way to classic pragmatism and its original insight.

Moreover, I think the figure of the cosmopolitan, open-minded Rortyan liberal ironist is highly questionable in Romano's own terms insofar as his politics belongs to a small élite of well-educated people so that at the end Romano risks to be entrapped in the same cage of the white-man culture from which he wants to break free. However, Romano poses a serious challenge to any professional philosopher with his question. If what you do and think is so important to our society, how is that it does not arrive to anyone? The long alternative cavalcade in other fields that Romano presents obliges everyone to think about the public import of our theories and inspires to be a little more courageous in proposing our ways to complete pragmatism and to foster our ideals. When James met the Italian pragmatists in Rome in 1905 he wrote to Alice saying that they taught him "courage" (James 2003: 197). I guess he referred to the courage of carrying on ideas and of putting them into practice, without false reverence to anyone. I think that Romano taught us the same lesson.

\section{AUTHORS}

\section{GIOVANNI MADDALENA}

Università del Molise

maddalena[at]unimol.it 